\title{
Lusioersily
}

\section{Person-centred end-of-life curriculum design in adult pre-registration undergraduate nurse education: a three-year longitudinal evaluation study}

Goode, D., Black, P., \& Lynch, J. (2019). Person-centred end-of-life curriculum design in adult pre-registration undergraduate nurse education: a three-year longitudinal evaluation study. Nurse Education Today, 82, 8-14. https://doi.org/10.1016/j.nedt.2019.07.009

Link to publication record in Ulster University Research Portal

\section{Published in:}

Nurse Education Today

Publication Status:

Published (in print/issue): 30/11/2019

DOI:

10.1016/j.nedt.2019.07.009

\section{Document Version}

Author Accepted version

\section{General rights}

Copyright for the publications made accessible via Ulster University's Research Portal is retained by the author(s) and / or other copyright owners and it is a condition of accessing these publications that users recognise and abide by the legal requirements associated with these rights.

\section{Take down policy}

The Research Portal is Ulster University's institutional repository that provides access to Ulster's research outputs. Every effort has been made to ensure that content in the Research Portal does not infringe any person's rights, or applicable UK laws. If you discover content in the Research Portal that you believe breaches copyright or violates any law, please contact pure-support@ulster.ac.uk. 


\section{Journal Pre-proof}

Person-centred end-of-life curriculum design in adult preregistration undergraduate nurse education: A three-year longitudinal evaluation study

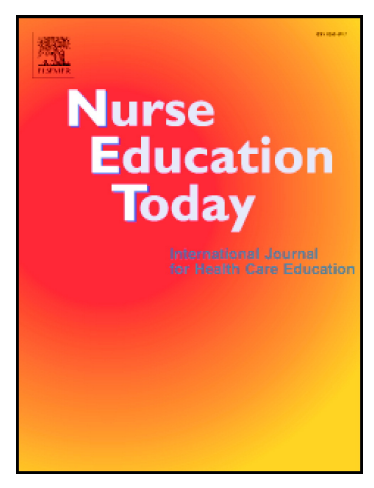

Debbie Goode, Pauline Black, Jacinta Lynch

PII: $\quad$ S0260-6917(18)30999-7

DOI: $\quad$ https://doi.org/10.1016/j.nedt.2019.07.009

Reference: $\quad$ YNEDT 4180

To appear in: $\quad$ Nurse Education Today

Received date: $\quad 21$ November 2018

Revised date: $\quad 30$ May 2019

Accepted date: $\quad 30$ July 2019

Please cite this article as: D. Goode, P. Black and J. Lynch, Person-centred end-oflife curriculum design in adult pre-registration undergraduate nurse education: A threeyear longitudinal evaluation study, Nurse Education Today(2019), https:/doi.org/10.1016/ j.nedt.2019.07.009

This is a PDF file of an article that has undergone enhancements after acceptance, such as the addition of a cover page and metadata, and formatting for readability, but it is not yet the definitive version of record. This version will undergo additional copyediting, typesetting and review before it is published in its final form, but we are providing this version to give early visibility of the article. Please note that, during the production process, errors may be discovered which could affect the content, and all legal disclaimers that apply to the journal pertain.

(C) 2019 Published by Elsevier. 
PERSON-CENTRED END-OF-LIFE CURRICULUM DESIGN IN ADULT PRE-REGISTRATION UNDERGRADUATE NURSE EDUCATION: A THREE-YEAR LONGITUDINAL EVALUATION STUDY

This is to certify that there has been no external funding source for this study and that there is no conflict of interests. This study has full ethical approval from Ulster University ethical committee.

We would like to acknowledge the contribution of Carole Mc Keeman, (Bereavement Coordinator, Western Health Social Care Trust) Emma King, (Macmillan Palliative Care Facilitator, Western Health Social Care Trust) Professor Assumpta Ryan, Professor Tanya McCance and Professor Kader Parahoo from Ulster University in the preparation of the paper.

Dr Debbie Goode Lecturer in Nursing Ulster University Northland Road L/Derry BT487JL Work 02871675219 Mobile 07966171488 D.Goode@ulster.ac.uk

Dr Pauline Black Lecturer in Nursing Ulster University Mrs Jacinta Lynch Lecturer in Nursing Ulster University 


\section{Person-centred end-of-life curriculum design in adult pre-registration undergraduate nurse education: a three-year longitudinal evaluation study}

\section{(5500 words)}

\section{Abstract}

\section{Background}

The need to provide quality end-of-life care is universally accepted. International research and policies encourage innovative ways that effective culturally appropriate care can be provided. Higher education institutions and practice settings are tasked with ensuring that nurse graduates have the knowledge, skills and insight to deliver person-centred end-of-life care.

\section{Research Aims and Objectives}

The aim was to explore student evaluation of end-of-life care learning within a threeyear undergraduate adult nursing degree programme. Objectives were to assess student perceptions of the content and level of learning achieved, explore usefulness of learning, highlight areas that were most useful, and identify suggestions to improve learning.

Design

A 3-year quantitative longitudinal design was used. A questionnaire containing open and closed questions was designed to incorporate the personal and professional learning strategies indicated by the Nursing and Midwifery Council (NMC) (2010).

\section{Setting and Participants}

The evaluation was completed at the same time point over a three-year period from April 2015 - April 2017. The participants were year three student nurses, from 3 consecutive years, enrolled on a pre-registration adult nursing course at one university. There was a $66 \%$ response rate $(n=336)$. 


\section{Methods}

Participant information sheets and questionnaires were distributed and time to complete them facilitated. Responses from closed questions were coded and analysed using descriptive statistics (SPSS 24) and thematic analysis used for open questions.

\section{Results}

Students expressed satisfaction with their learning, $88.7-97 \%$ of students reported a positive impact on their knowledge. They developed an understanding of the impact the nurse can have on the patient and family experience, reporting more confidence and competence in most aspects of end-of-life care. They noted improved ability to utilise this in their subsequent practice experience $88.1-97 \%$.

\section{Conclusions}

Structured end-of-life care within the curriculum is essential to equip graduate nurses to provide effective evidence informed care. Planning should continue for curriculum development that encompasses person-centred end-of-life care across cultures.

\section{Keywords}

End-of-life care; nursing; curriculum; person-centred care; personcentredness; undergraduate. 


\section{Background/Introduction}

The need to provide quality end-of-life care is universally accepted. International research and policy development attempt to identify common features of end-of-life care and encourage innovative ways in which effective and culturally appropriate care can be given (Zaman et al 2017). The World Health Organisation (WHO)(2014) estimates that worldwide, in 2011, over 20 million individuals required specialist care at the end-of-life. It is projected that $37 \%$ of people dying will require specialist end-oflife care. In 2002 Singer and Bowman conceptualised provision of quality end-of-life care as a global public health and health systems problem and emphasised the need for capacity to deliver care to be improved and strengthened. To have relief of pain and dignity in death is seen as an international human right (Brennan 2007), requiring urgent and sensitive strategies that address a range of barriers that include the integration of end-of-life care into the undergraduate and continuing professional education of all health professionals. To achieve this, the WHO (2014) recommend a focus on palliative and end-of-life care across global and national health agendas.

Regional government strategy emphasises the importance of person-centredness in health and social care in the United Kingdom (UK) (Department of Health, Social Services and Public Safety 2011; Department of Health 2012; NHS Scotland 2013; Williams 2013). Improving the delivery of end-of-life care has been the focus of attention by the Department of Health (2008), General Medical Council (2010) and the Royal College of Nursing (2015). Clinical guidelines have been developed to assist in care of the dying patient (NICE 2015). The National Institute for Health Care Excellence Guidance on end-of-life care (NICE 2015; 2017) emphasises workforce training and planning to ensure care providers are competent to deliver quality care for people at the end-of-life. Higher education institutions and practice settings are tasked with ensuring that nursing students graduate with the knowledge, skills and insight to deliver end-of-life care (NMC 2018a\&b).

\section{Literature}

A search for literature was performed using the online databases; CINAHL plus Medline, Science Direct and USearch (EBSCO) (see Table 1) Insert Table 1 here 


\section{Need for specific curriculum content}

The need for specific education and knowledge of the principles underpinning effective practice in end-of-life care has been repeatedly highlighted internationally (De Souza and Pettifer 2013; Adesina et al. 2014). This is also an interprofessional concern as medical, nursing and pharmacy students identified that clinical care at the end-of-life remained challenging and more training would be beneficial (Jansen et al 2013). Glover et al (2017) report that $85 \%$ of student nurses had not received adequate training for end-of-life care. Preparation and training of educators is also essential (Jie et al 2018; Takenouchi et al 2018).

\section{Equipping students to provide effective end-of-life care}

Student nurses require continuous support when developing personal coping strategies in clinical and educational settings (Ek et al. 2014). It is vital that the interdisciplinary team members who have the most contact with the patient and their family are competent to provide evidence informed, person-centred end-of-life care (Adesina et al. 2014). Jackson and Motley (2014) reported findings from final year students on a half-day seminar on end-of-life care which evaluated the teaching positively. They identified beneficial learning about communication and provision of holistic care in end-of-life situations. In North America, the End-of-Life Nurse Education Consortium training has received positive evaluations for the resultant impact on attitude and knowledge with successful international and cultural translation to the Far East context (Paice et al 2008; Jackson and Motley 2014; Jie 2018; Tackenouchi et al 2018). Evans (2017) suggests the inclusion of palliative care teaching across the whole nursing curriculum would improve care for patients at endof-life, yet Lippe et al (2017), while reporting development of knowledge and attitudes toward end-of-life care with academic progression, found deficiencies persisted that required further education and training.

Research and evaluation of end-of-life care remains challenging. The evidence base emerges from developed countries and is heavily weighted towards the perspectives of Western society and conventional medicine (Zaman 2015). While commending the development of end-of-life education programmes published in English, the WHO 
(2014) highlight these require translation of language and cultural context and their curricular impact needs international comparative research to establish effectiveness. Zaman et al (2017) highlight the need to identify the indicators of quality end-of-life care that are shared across countries and from there to develop localised and culturally appropriate provision of care.

To identify the direction that future end-of-life learning must take, educators need to recognise emergent trends in delivery of end-of-life care. In 2014, the WHO questioned the sustainability of end-of-life care within specialist settings, suggesting that end-of-life care will integrate into mainstream, independent and voluntary sector provision. The emergence and growth of training programmes for end-of-life serves to confirm the diversification of end-of-life care and the need for individualised support and meaningful engagement for people and their families.

\section{Pedagogical approaches to support learning in end-of-life care}

Various educational strategies are suggested in the literature to address these deficits. The use of simulation has been explored and found to be beneficial to the student, allowing exploration of ethical dilemmas in a safe environment (Kopka et al. 2016). Gannon et al (2017) reported success in changing attitudes by using interprofessional end-of-life simulation. Gillian et al (2014), however, urge that caution should be exercised during simulation to ensure the psychological safety of students. Students who have personal experiences of loss have demonstrated increased awareness of the challenges in care provision and Jie et al (2018) recommend that educators should be aware of the needs of students who have, and who have not, experienced loss and adapt student group composition to reflect both perspectives. Other pedagogical approaches that improve knowledge and confidence include online courses (Conner et al. 2014), high fidelity and gaming approaches (Montgomery et al. 2016) and use of real-life case studies (Bailey and Hewison 2014). The use of multiple learning strategies was used by Bailey et al (2017) in a global classroom education experience where students collaborated, interacting on a virtual learning platform and enhancing their individual learning.

Exploration of the evidence confirmed the need for considered and integrated curriculum and pedagogical development in end-of-life care. Where evaluations of 
specific educational interventions have been reported, these have been single events delivered at specific timepoints near the end of nurse education programmes. To date no evidence was found of a programme wide approach to person-centred end-of-life teaching. The aim of this study was to explore student evaluation of the delivery and educational impact of an integrated, progressive curriculum on end-of-life care delivered across a three-year undergraduate adult nursing degree programme.

Objectives for the evaluation were to:

- assess student perceptions of the content and level of learning achieved,

- explore usefulness of learning to both clinical practice and personal life,

- identify areas of learning students found most useful, and

- develop strategies to improve learning within each year of the programme.

\section{Context of curriculum development}

The undergraduate nurse education curriculum presented in this paper was developed using the theoretical and philosophical principles of the Person-Centred Nursing Framework (McCormack and McCance 2010). This was introduced through increasing awareness of self and critical thinking, clarity of beliefs and values, and the importance of professionalism, teamwork and personhood throughout the three-year programme. McCormack and McCance (2010) outline four key constructs of the person-centred practice framework: prerequisites, the context of care provision, care processes and person-centred outcomes (satisfaction with care, involvement with care, a feeling of well-being and the creation of a therapeutic culture).

Person-centred end-of-life care should enable the professional, patient and family to work in partnership to make decisions and manage care that is individualised, dignified, compassionate and respectful. Regional initiatives to support this led to the development of The Northern Ireland Bereavement strategy (DH 2009) which links closely with the Person-Centred Practice Framework (McCormack and McCance 2010). New graduate nurses must be equipped with the tools to deliver end-of-life care in a compassionate, sensitive manner embracing the personal beliefs, cultures, and practices of individuals and their families and carers. In partnership with a hospital 
bereavement coordinator and a palliative care facilitator, an educational initiative was designed to achieve this and to integrate the Northern Ireland Bereavement Care Strategy (DH 2009) and the Final Journeys (Irish Hospice Foundation) training into the learning and teaching strategy for end-of-life care across all three years of the undergraduate programme (Table 2). This design incorporated professional and personal/emotional aspects to promote increased competency and familiarisation with the concept of end of life care.

\section{Integrating end-of-life care into the curriculum}

Student learning outcomes and competencies were mapped across the programme in theoretical and skills-based teaching. Planning was essential to identify the themes and learning outcomes that would be addressed across the three years of the programme (NMC 2010; 2018b). Inclusion of staff with expertise and interest in endof-life care ensured greater consistency and relationship building. Attention to staff training needs allowed the development of strategies to assist in teaching the topic sensitively. Cognisance was also given to the need to provide support to both staff and students, when teaching and learning end-of-life care. The partnership approach with Hospital Trust and Macmillan Cancer Relief Organisation and university colleagues was a vital component in this process. Assessment of achievement of learning outcomes was integrated into coursework, examinations and practice for each part of the programme and the impact of learning about end-of-life care in an integrated curriculum was measured by student evaluation. The pedagogical approaches used are shown in Table 2. In each year of the programme, students were supported by registered nurses as their learning was applied in hospital and community practice settings.

Insert Table 2 here

\section{Research Design and Methods}

\section{Ethics}

Ethical approval to undertake a student evaluation of the integrated end-of-life curriculum over a three-year period was obtained through the University ethics 
committee. Ethical principles as identified by International Council for Nurses (ICN) (2012) were adhered to during the study.

\section{Design}

A longitudinal quantitative approach to data collection was utilised to evaluate student learning. As no validated tools were available, a questionnaire, containing open and closed questions, was designed to incorporate the personal and professional learning strategies indicated by the NMC (2010). The questionnaire was piloted with third year students $(n=2)$ and was reported as clear and understandable. These students were excluded from the sample. The participants were year three students within one programme. The evaluation was completed at the same time point with final year students during April 2015, April 2016 and April 2017.

\section{Data Collection and Analysis}

Participant information sheets describing the nature and purpose of the evaluation and a copy of the questionnaire were distributed to students during an annual designated class by a member of staff who was not involved in the end-of-life teaching. Time to complete during class was facilitated. Students were informed verbally and in writing that participation was voluntary and that responses were anonymous. Implied consent was assumed by return of the completed evaluations. Completed evaluations were collected by student representatives after completion and returned to the researchers in a box provided. Responses from closed questions were coded and analysed using descriptive statistics in SPSS statistical package (version 24). Thematic analysis was used to analyse qualitative data in the responses to open questions (Burns and Grove 2009). Quotes to support the themes are attributed to respondents by code number.

\section{Findings}

The total number of students enrolled over the three-year period was 513 and 336 questionnaires were completed equating to $66 \%$ response rate. Data on the age and gender of the respondents was not collected as comparative analysis based on these variables was not planned. All questions were not answered by every student giving variation in total answers. 


\section{Appropriateness and usefulness of learning about end-of-life care}

The majority of students reported being satisfied with the academic level of teaching and learning about end-of-life care across the three years of the programme (year 1 $=88.7 \%$, year $2=97 \%$ and year $3=88.7 \%$ (Table 3 ). Some respondents (Transfer student TF, $n=7$ ) completed year one at another institution and transferred to the programme at the start of year two. This means that data collected from them applied to year 2 and 3 only.

\section{Insert Table 3 here.}

Students were asked to evaluate the usefulness of skills to critically reflect, exercise self-care and navigate challenges during end-of-life situations in both their personal life and clinical practice experience. The skills were evaluated as useful in their personal life and clinical practice experience by the majority of students in year 1 (74.6\% and $88.1 \%)$, year 2 (82.1\% and $97 \%)$ and year $3(81.7 \%$ and $89.6 \%)$ (Table 4).

Insert Table 4 here.

\section{Student learning}

Students were asked to identify aspects of their learning about end-of-life care that made the most impression on them. Each respondent could write several answers, and these were coded separately and presented in Table 5.

\section{Insert Table 5 here.}

Students responded most frequently that in year one they valued the introduction and insight into the topic (46.1\%), something that was not experienced before in any context. Being prepared to deal with death in clinical practice settings was also a common answer (34.8\%). One student reported that they were now 'able to understand and deal with own emotions when dealing with end-of-life care' (16). Another student stated that it 'made me think towards my own future. Realised in that 
situation the smallest things can make the biggest difference' (154). Commenting about self-care, a student wrote: 'The focus on oneself often is a forgotten aspect as you try to place the patient and family above all else' (5).

In year two, learning person-centred skills for end-of-life care was the most useful (44\%) with the knowledge and practice in breaking bad news also viewed as useful $(34.2 \%)$. A student recalled that the teaching was 'started gently on a sensitive topic and built on it in the following years' (15). Another student explained that the teaching 'helped me to gain more in-depth knowledge of end-of-life and how to communicate with patients and families regarding this' (134). Learning the principles of 'breaking bad news was helpful, providing a more structured way of communicating bad news to patients and families' (2). This was supported by another student stating that the 'development of skills enabled you to deal with sensitive cases while showing care and compassion' (6).

Students reported that learning in year 3 improved their knowledge and confidence $(31.5 \%)$ and developed their leadership skills $(11.9 \%)$. They indicated that the teaching provided a clear insight into palliative care. Improved self-awareness and focus on self-care were also reported. Significant learning for cultural awareness was evident: 'It gave good background knowledge, on which to build and examples enabled me to be less worried and reduced the taboo aspects of end-of-life' (1). "The teaching expanded my knowledge of cultures other than my own and how they deal with death and dying" (135).

Increased awareness of person-centred practice was apparent, one student commenting that 'I feel it taught me to be more patient focused (putting the patient at centre of care) giving the patient time in practice' (133). Another student described being prepared for going out on practice learning: '[lt] enabled me to use coping strategies when faced with that challenge [death and dying]' (239). This was supported by other comments that 'it was good preparation for practice to know ways of personally dealing with witnessing death and although still daunting, slightly easier [when] supporting patients and families dealing with a bereavement' (262). Their learning highlighted 'ethical considerations during end-of-life care. This put in perspective individualised care at end-of-life and the importance of communication' 
(12). One student reported the value of the Safe Talk suicide awareness training stating that 'the teaching was interesting it made me aware of how different groups come together to help victims and families' (18).

Their involvement in the community resilience event and the Immediate Life Support course were also relevant as it exposed them to different contexts for end-of-life care. These provided learning opportunities to consolidate learning and practical skills developed through each year of the curriculum. A student referred to the usefulness of these events in 'pulling it all together' (20), and another student stated that it gave 'good insight into what is expected of me as a registered nurse when developing skills and knowledge in end-of-life care' (17) and a student reflected that 'coming to year three you begin to feel nervous about the impending role, but you know you have the knowledge to deliver end-of-life care it's just about putting more confidence into what we know (19).

\section{Student suggestions for future development}

Students requested more use of scenarios in year one including more practical application of the principles of end-of-life care $(n=92,27.4 \%)$. Some students requested more teaching about communication with the family ( $n=21,6.3 \%)$, how to deal with their own personal distress $(n=15,4.5 \%)$, types of medication in end-of-life care $(n=12,3.6 \%)$ and more focus on palliative care $(n=11,3.3 \%)$. Of the respondents $(n=77) 22.9 \%$ wished for nothing to be added to teaching in year one.

Students felt the problem based learning and practical examples were very useful and requested more of them in year two $(n=111,33 \%)$. More information about medication used in end-of-life care was requested $(n=13,3.9 \%)$. Further insight into how to provide family support was requested by $(n=10,3 \%)$ and how to deal with a traumatic death $(n=7,2.1 \%)$. Of the respondents $(n=82) 24.4 \%$ felt that nothing needed to be added to year 2 teaching.

Students suggested that more use be made of role play and skills scenarios in year three teaching $(n=66,19.6 \%)$. More time for end-of-life teaching was requested by $17.9 \%(n=60)$. Suggestions to increase the teaching on medication $(n=27,8 \%)$, the patient and family experience $(n=17,5.1 \%)$, skill development in communication 
$(n=11,3.3 \%)$ and care pathways and managing death $(n=7,2.1 \%)$ were made. Of the respondents $20.8 \%(n=70)$ felt that nothing additional was needed in year 3 of the programme.

- Students were given the opportunity to comment on anything that they felt had not been covered in the questionnaire. No suggested improvement was indicated by $33.9 \%(n=114)$ of respondents with $8.6 \% \quad(n=29)$ of students recording that they had enjoyed the teaching on end-of-life care in the programme. Suggestions to increase teaching on personal implications of endof-life care (including talking to the family) were made by $2.7 \%(n=9)$, end-oflife care planning $(n=6,1.8 \%)$ and making difficult decisions, in particular, do not attempt resuscitation (DNAR $n=5,1.5 \%$ and legal or ethical issues $n=2$, $0.6 \%)$.

\section{Discussion}

Students agreed that the level of teaching was appropriate for each of the three years of the programme. A higher level of satisfaction was reported for the level of learning in year two of the programme. In year two students spend a full week learning the principles of end-of-life care and applying that knowledge to practice in skills classes. The timetable was designed to coincide with a regional hospice care week and representatives from practice were invited to speak to students about hospice care. This focus on knowledge, practice and skills development may have contributed to the greater student satisfaction reported.

Supporting the evidence from Ek et al. (2014), students agreed that their learning in end-of-life care had been useful in both their personal and professional lives. The findings indicate usefulness of end-of-life care knowledge in their personal lives over the three years of the programme. This illustrates how knowledge crosses over from the classroom to practice but also how personal development and values can be influenced by professional understanding. This has the potential to strengthen the prerequisites required for effective person-centred care and self-awareness (McCormack and McCance 2010). Encouraging students to explore what was important to them and to identify the direction their life was taking helped them to explore personal values and beliefs as an essential component for reflection. Students 
reported the usefulness of the learning for their practice experiences, again with an increase in usefulness reported for year two of the programme (Ek et al. 2014).

The aim of the teaching was to allow students to enhance their communication skills and develop self-awareness in challenging situations. Integrating a variety of pedagogical approaches to encourage problem-based learning, facilitating role play and exploration of audio-visual resources encouraged students to reflect on the impact of effective management of end-of-life care for people and their families (Walker and Deacon 2016). Second year students identified development of sensitivity in their communication skills and reported feeling more confident in their ability to begin to create an environment for effective end-of-life care (Jackson and Motley 2014). This underpins the value of a scaffolded approach to end-of-life education, establishing sound values upon which care processes can be built which would be in keeping with guidance from NHS England (2014) Actions for End of Life Care and Leadership Alliance for Care of Dying People report One Chance to Get it Right (2014).

In year three the theory and practice aspects of learning were designed to reflect increasing complexity to equip students with the necessary knowledge and skills to provide person-centred end-of-life care in a changing health care environment at the point of registration (NMC 2010, 2018a). They recognised that at this stage they were able to assimilate their learning and apply it to their decision making and reflection in complex case scenarios. Consequently, students identified growth in their practice confidence and preparedness to deliver person-centred outcomes in end-of-life-care which is identified as an area of need by Hunter and Orlovic (2018).

While students evaluated the integrated end-of-life care curriculum as making a positive contribution to their learning, learning for educators was also identified Student suggestions for further development and up to date evidence are integrated into the curriculum as it evolves in each academic year to ensure that the content is dynamic and reflective of current practice (Wallace et al 2009). One area that is currently being developed is the preparation of students to deliver effective and culturally sensitive end-of-life care in a range of international settings. 


\section{Recommendations}

Several recommendations for future educational development include the need to:

- Ensure that learning is structured and scaffolded across programmes of study.

- Consider ways to internationalise the curriculum and integrate cross disciplinary person-centred learning opportunities.

- Be aware that the student learning experience impacts on both professional practice and personal life and requires appropriate consideration during the planning of teaching and provision of support if required.

- Encourage an appreciation of the differing perspectives towards end-of-life held by people across the world to provide care that is culturally and contextually agile.

- Involve voluntary and independent sectors as well as primary and secondary health and social care providers in the planning and delivery of end-of-life education.

\section{Limitations}

The response rate of $66 \%$ is relatively low for a captive population, although participation was entirely voluntary. The figure was calculated across all three years and was based on the number of students registered in each cohort. Some students may have been absent, or on a period of leave from the programme at that time, others may have had low motivation to participate. Waiting to complete the evaluation of endof-life learning during the final year of the three-year undergraduate programme relies on accurate student recall. While this may be considered a valid limiting factor, it may have captured the cumulative effect as they reflected on their learning and development. The questionnaire was self-designed and therefore does not have established validity and reliability. It was structured around the NMC (2010) learning outcome statements for pre-registration nurse education. The use of dichotomous yes or no responses was planned for ease of application and this may have limited variation in responses, however, open-ended questions allowed students to elaborate where required to express their opinion. The application of student learning to practice relies on their actual participation in care and is thus reliant on opportunities in clinical practice experience and exposure to the care of a person at end-of-life. Opportunities for participation in end-of-life care in practice were not measured by this evaluation 
and it is possible that students may have been influenced by their participation, or not, in end-of-life care

\section{Conclusion}

The results of the evaluation are positive. Students expressed satisfaction with their learning and made suggestions for future inclusion. They developed a clear understanding of the impact a nurse has on the patient and family experience. They reported increased confidence and competence in their approach to end-of-life care, recognising the professional and personal implications of caring in a person-centred manner. The continuing challenge for educators is the effective preparation of nurses who are equipped with the skills to work across geographical borders, funding sectors and care agencies to provide care that focuses on the person and their families and meets the diversity of meaning and expectation in end-of-life care. Developing their appreciation of the value of person-centred practice and their confidence in applying the principles to end-of-life care is a springboard to achieve this goal. 


\section{Reference List (1073 words)}

Adesina, O., DeBellis, A. and Zannettino, L. 2014. Third-year Australian nursing students' attitudes, experiences, knowledge, and education concerning end-of-life care. International Journal of Palliative Nursing, 20 (8), 395-401.

Bailey, C. and Hewison, A. 2014. The impact of a ' Critical Moments' workshop on undergraduate nursing students' attitudes to caring for patients at the end of life: an evaluation. Journal of Clinical Nursing, 23 (23/24), 3555-3563.

Bailey, C, Hewison, A, Orr, S, \& Baernholdt, M. 2017. Learning About End-of-Life Care in Nursing--A Global Classroom Educational Innovation. Journal Of Nursing Education, 56, (11), 688-691.

Brennan, F 2007. Palliative care as an international human right. Journal of Pain and Symptom Management, 33, (5), 494-499.

Burns, N and Grove, K. 2009. The Practice of Nursing Research Appraisal Syntheses and Generation of Evidence. $6^{\text {th }}$ ed. St Louis: Saunders Elsevier.

Conner, N., Wochna Loerzel, V. and Uddin, N. 2014. Nursing Student End-of-Life Care Attitudes After an Online Death and Dying Course. Journal of Hospice and Palliative Nursing, 16 (6), 374-382.

Department of Health. 2008. End-of-life care strategy: promoting high quality care for all adults at the end of life. London: $\mathrm{DH}$.

Department of Health. 2012. Health and Social Care Act. Section 13H. Available at: http://www.legislation.gov.uk/ukpga/2012/7/contents/enacted [Accessed: 26 April 2017].

Department of Health. 2009. Northern Ireland Health and Social Care Services Strategy for Bereavement Care. Belfast: DHSSPS. Available at: 
http://www.dhsspsni.gov.uk/nihsc-strategy-for-bereavement-care-june-2009.pdf [Accessed: 26 April 2017].

Department of Health, Social Services and Public Safety. 2011. A 10-year strategy to protect and improve quality in health and social care. Belfast: DHSSPS.

De Souza, J. and Pettifer, A. 2013. End-of-life Nursing Care - A guide for best practice. London: Sage Publications.

Ek, K., Westin, L., Prahl, C., Österlind, J., Strang, S., Bergh, I., Henoch, I. and Hammarlund, K. 2014. Death and caring for dying patients: exploring first-year nursing students' descriptive experiences. International Journal of Palliative Nursing, 20 (10), 509-515.

Evans, C. 2017. Effects of an Educational Intervention on RN to BSN Students' Knowledge of Palliative Care. Kentucky Nurse, 65, (2), 15.

Gannon, J, Motycka, C, Egelund, E, Kraemer, D, Smith, W, \& Solomon, K. 2017. Teaching End-of-Life Care Using Interprofessional Simulation. Journal Of Nursing Education, 56, (4), 205-210,

General Medial Council. 2010. Treatment and care towards the end of life: good practice in decision making. Manchester: GMC. Available at: http://www.gmcuk.org/guidance/ethical guidance/end of life care.asp [Accessed: 20 April 2017].

Gillian, P., van der Riet, P. and Jeong, S. 2014. End-of-lifecare education, past and present: A review of the literature. Nurse Education Today. 34, (3), 331-3.

Glover, T, Garvan, C, Nealis, R, Citty, S, \& Derrico, D. 2017. Improving End-of-Life Care Knowledge Among Senior Baccalaureate Nursing Students. American Journal Of Hospice \& Palliative Medicine, 34, (10), 938-945. 
Hunter, J, and Orlovic, M. 2018. End of life care in England. A briefing paper. London: Institute for Public Policy Research.

International Council of Nurses. 2012. Code of Ethics for Nurses. Geneva: ICN.

Irish Hospice Foundation Final Journeys Education and Training. Available at: http://hospicefoundation.ie/education-training/staff-training/ [Accessed 1.6.18].

Jackson, M. and Motley, C. 2014. End-of-Life Educational Seminar in a Prelicensure Bachelor of Science in Nursing Program. Journal of Hospice and Palliative Nursing, 16 (6), 348-354.

Jansen, B, Parsons, C, Hughes, C, Weckmann, M, \& Nguyen, C. 2013. A crossnational cross-sectional survey of the attitudes and perceived competence of finalyear medicine, nursing and pharmacy students in relation to end-of-life care in dementia. Palliative Medicine, 27, (9), 847-854.

Jie, L, Supiano, K, Madden, C, \& McLeskey, N. 2018. The Impact of the End-of-Life Nurse Education Consortium on Attitudes of Undergraduate Nursing Students Toward Care of Dying Patients. Journal Of Hospice \& Palliative Nursing, 20, (4), 340-348.

Kopka, J.A., Aschenbrenner, A.P. and Reynolds, M.B. 2016. Helping Students Process a Simulated Death Experience: Integration of an NLN ACE.S Evolving Case Study and the ELNEC Curriculum. Nursing Education Perspectives. 37(3),180-182.

Leadership Alliance for the Care of Dying People. One Chance to Get it Right . London: UK Government, 2014.

https://www.gov.uk/government/uploads/system/uploads/attachment_data/file/32318 8/One_chance_to_get_it_right.pdf.

Lippe, M, Jones, T, Becker, H, \& Carter, P. 2017. Student Preparation to Care for Dying Patients: Assessing Outcomes Across a Curriculum. Journal Of Nursing Education. 56, (10), 633-637. 
Montgomery, M., Cheshire, M., Johnson, P. and Beasley, A. 2016. Incorporating endof-life content into the community health nursing curriculum using high-fidelity simulation. Journal of Hospice and Palliative Nursing, 18(1), 60-65.

McCormack, B. and McCance, T.V. 2010. Person-centred Nursing: Theory and Practice. Oxford: Wiley-Blackwell.

National Institute for Health Care Excellence. 2015. Care of dying adults in the last days of life NICE guideline [NG31]. London: NICE.

National Institute for Health Care Excellence. 2017. End-of-life care for adults. Quality standard [QS13]. London: NICE.

National Health Service England. 2014. Actions for End of Life Care: 2014-16. Leeds: NHS England.

National Health Service Scotland. 2013. Everyone Matters: 2020 Workforce Vision. Edinburgh: APS Group Scotland.

Nursing and Midwifery Council. 2010. Standards for pre-registration nursing education. London: NMC.

Nursing and Midwifery Council. 2018a.The Code. Professional Standards of practice and behaviour for nurses, midwives and nursing associates. London: NMC.

Nursing and Midwifery Council. 2018b. Future nurse: Standards of proficiency for registered nurses. London: NMC.

Paice, J, Ferrell, B, Coyle, N, Coyne, P, \& Callaway, M. 2008. Global efforts to improve palliative care: the International End-of-Life Nursing Education Consortium Training Programme. Journal Of Advanced Nursing, 61, (2) ,173-180.

Royal College of Nursing. 2015. Getting it right every time. Fundamentals of nursing care at the end of life. London: RCN. 
SafeTalk Training. Available via http://www.westerntrust.hscni.net/about/2608.htm Accessed on 9.8.18

Singer, P.A. \& Bowman, K.W. 2002. Quality end-of-life care: a global perspective. BMC Palliative Care. 1: 4 available at https://bmcpalliatcare.biomedcentral.com/articles/10.1186/1472-684X-1-4 (accessed on 12.9 .18

Takenouchi, S., Tomoyo, S, Mitsunori, M, Masako, K, Megumi, U, Miyoko, K, Tomoko, A, Yoshiyuki, K, \& Keiko, T. 2018. Empowering Nurses Through Translating the Endof-Life Nursing Education Consortium: The End-of-Life Nursing Education Consortium--Japan Core Curriculum Project. Journal Of Hospice \& Palliative Nursing, 19, (6), 539-549.

Walker, W. and Deacon, K. 2016. Nurses' experiences of caring for the suddenly bereaved in adult acute and critical care settings, and the provision of person-centred care: A qualitative study. Intensive and Critical Care Nursing, 33, 39 - 47.

Wallace, M., Grossman, S., Campbell, S., Robert, T., Lange, J. and Shea, J. 2009. Integration of end-of-life care content in undergraduate nursing curricula: student knowledge and perceptions. Journal of Professional Nursing, 25 (1), 50-56.

Williams, A. 2013. The listening organisation: Ensuring care is person-centred in NHS Wales. Cardiff: 1000 Lives Plus.

World Health Organisation (2104) Global atlas of palliative care at the end of life.

Worldwide Palliative Care Alliance. Available at:

http://www.who.int/nmh/Global Atlas of Palliative Care.pdf [Accessed 12 September 2018].

Zaman, S. 2015. Challenges of studying end of life care in the global context. 10 April. Available at: http://endoflifestudies.academicblogs.co.uk/challenges-of-studying-endof-life-care-in-the-global-context/ [Accessed 12 September 2018]. 
Zaman, S, Inbadas, H. Whitelaw, A and Clark, D. 2017. Common or multiple futures for end of life care around the world? Ideas from the waiting room of history. Social Science and Medicine, 172, 72-79. 


\begin{tabular}{|c|c|}
\hline \multicolumn{2}{|c|}{ Key search terms } \\
\hline end-of-life & curriculum \\
\hline \multicolumn{2}{|c|}{$\begin{array}{l}\text { Search modes and expanders were to 'apply equivalent subjects', 'apply related words' } \\
\text { and 'also search within full text'. }\end{array}$} \\
\hline Inclusion criteria & Exclusion criteria \\
\hline Available in English & Published in a language other than English \\
\hline $\begin{array}{l}\text { Published between January } 2005 \text { and } \\
\text { September } 2018\end{array}$ & Discussion and editorial papers \\
\hline \multicolumn{2}{|l|}{ Limited to academic journals } \\
\hline \multicolumn{2}{|l|}{ Peer-reviewed } \\
\hline \multicolumn{2}{|l|}{ Systematic literature reviews } \\
\hline Human Research & 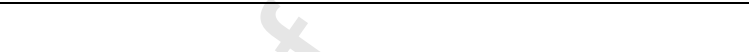 \\
\hline
\end{tabular}

Table 1: Search terms, inclusion and exclusion criteria. 


\begin{tabular}{|c|c|c|c|c|}
\hline $\begin{array}{l}\text { Student } \\
\text { Year } \\
\text { Group }\end{array}$ & $\begin{array}{c}\text { Person- } \\
\text { centred } \\
\text { Practice } \\
\text { Framework }\end{array}$ & Curriculum Design & Pedagogical approaches & Tips for Lecturer \\
\hline Year 1 & $\begin{array}{l}\text { Clarity of } \\
\text { beliefs and } \\
\text { values. } \\
\text { Knowing self. } \\
\text { Shared } \\
\text { decision- } \\
\text { making } \\
\text { systems. } \\
\text { Providing } \\
\text { holistic care. } \\
\text { Working with } \\
\text { the patient's } \\
\text { beliefs and } \\
\text { values. }\end{array}$ & $\begin{array}{l}\text { - Introduce theories of grief } \\
\text { and dealing with death. } \\
\text { - Culture and diversity } \\
\text { awareness. } \\
\text { - Learn how to support and } \\
\text { communicate with people } \\
\text { and integrate care to } \\
\text { meet needs of people } \\
\text { who are dying and their } \\
\text { families, friends and } \\
\text { carers. } \\
\text { - Recognise the need for } \\
\text { time, privacy, dignity and } \\
\text { respect for those who are } \\
\text { dying and their families. } \\
\text { - Raise awareness of } \\
\text { regional, national and } \\
\text { international statistics on } \\
\text { end-of-life care. } \\
\text { - Move from asking 'what's } \\
\text { the matter?' to 'what } \\
\text { matters to you?'. } \\
\text { - Values clarification } \\
\text { exercise. } \\
\text { - Importance of self-care } \\
\text { and reflection. }\end{array}$ & $\begin{array}{l}\text { Focused preparatory } \\
\text { learning } \\
\text { Lecture } \\
\text { Tutorials } \\
\text { Concept based learning } \\
\text { activities } \\
\text { - Role-play } \\
\text { - Video's } \\
\text { Simulation with mannequ }\end{array}$ & $\begin{array}{l}\text { Preparation for the } \\
\text { teaching is key in } \\
\text { particular: } \\
\text { - } \quad \text { a designated } \\
\text { team } \\
\text { - developing } \\
\text { succinct lesson } \\
\text { plans } \\
\text { ensure } \\
\text { exemplary } \\
\text { documentation } \\
\text { and props used } \\
\text { is current and } \\
\text { links to } \\
\text { relevant } \\
\text { practice } \\
\text { learning areas } \\
\text { Have an awareness } \\
\text { of recent } \\
\text { bereavements } \\
\text { within student } \\
\text { cohort } \\
\text { Permit students to } \\
\text { leave the room if } \\
\text { necessary }\end{array}$ \\
\hline Year 2 & $\begin{array}{l}\text { Professionally } \\
\text { competent. } \\
\text { Developed } \\
\text { interpersonal } \\
\text { skills. } \\
\text { Clarity of } \\
\text { beliefs and } \\
\text { values. } \\
\text { Having a } \\
\text { sympathetic } \\
\text { presence. }\end{array}$ & $\begin{array}{l}\text { - Develop knowledge of the } \\
\text { nurse's role in providing } \\
\text { person-centred end-of- } \\
\text { life care for the person } \\
\text { and the family. } \\
\text { - Emphasise } \\
\text { communication skills and } \\
\text { self-awareness in the } \\
\text { students, demonstration } \\
\text { of skills including active } \\
\text { listening, answering } \\
\text { difficult questions and } \\
\text { breaking bad news. } \\
\text { - Understand cultural and } \\
\text { spiritual variations in the } \\
\text { grieving process and } \\
\text { impact of the } \\
\text { environment where end- } \\
\text { of-life care is provided to }\end{array}$ & $\begin{array}{l}\text { Focused preparatory learning } \\
\text { Lecture } \\
\text { Tutorials and skill-based } \\
\text { scenarios including Final } \\
\text { Journeys training and Dying } \\
\text { Matters elearning. } \\
\text { Case based learning } \\
\text { - Case studies } \\
\text { - } \quad \text { Reflective practice } \\
\text { - Peer learning } \\
\text { - } \quad \text { Web enhanced } \\
\text { Simulation with mannequins/ } \\
\text { actors/ videos of service } \\
\text { users }\end{array}$ & $\begin{array}{l}\text { Consider having } \\
\text { additional staff to } \\
\text { offer guidance and } \\
\text { support } \\
\text { At the end of class } \\
\text { students must be } \\
\text { informed they can } \\
\text { discuss issues with } \\
\text { studies advisor/ } \\
\text { student support } \\
\text { Revisit core } \\
\text { elements of } \\
\text { learning when } \\
\text { teaching } \\
\text { recommences }\end{array}$ \\
\hline
\end{tabular}




\begin{tabular}{|c|c|c|c|c|}
\hline & & $\begin{array}{l}\text { the dying person and } \\
\text { family. } \\
\text { - Use of a variety of } \\
\text { validated tools to guide } \\
\text { practice e.g. SPIKES tool } \\
\text { and underpinning } \\
\text { theoretical and } \\
\text { philosophical principles. } \\
\text { - Self-awareness and self- } \\
\text { care in relation to caring } \\
\text { for the carer. } \\
\text { - Demonstrate the skills of } \\
\text { symptom control and } \\
\text { providing last offices in a } \\
\text { person-centred manner } \\
\text { for people from a range } \\
\text { of cultures and religious } \\
\text { faiths. }\end{array}$ & & \multirow{2}{*}{$\begin{array}{l}\text { following practice } \\
\text { learning experience. } \\
\text { Be mindful of } \\
\text { students that have } \\
\text { transferred in from } \\
\text { another university } \\
\text { Encourage the use } \\
\text { of the wealth of } \\
\text { online resources } \\
\text { available } \\
\text { Have service-user } \\
\text { involvement } \\
\text { Integrate into } \\
\text { assessment of } \\
\text { module i.e. Essay } \\
\text { examination } \\
\text { Encourage students } \\
\text { to link theory to } \\
\text { practice } \\
\text { experiences } \\
\text { debate current } \\
\text { issues } \\
\text { link decisions } \\
\text { to the NMC } \\
\text { Code (2015) }\end{array}$} \\
\hline Year 3 & $\begin{array}{l}\text { Commitment } \\
\text { to the job. } \\
\text { Developed } \\
\text { interpersonal } \\
\text { skills. } \\
\text { Effective staff } \\
\text { relationships. } \\
\text { Shared } \\
\text { decision- } \\
\text { making } \\
\text { systems. } \\
\text { Providing } \\
\text { holistic care. }\end{array}$ & $\begin{array}{l}\text { - Use of patient, family and } \\
\text { carers voices and } \\
\text { experiences to complete } \\
\text { Final Journeys training. } \\
\text { - Critiquing complex case } \\
\text { scenarios. } \\
\text { - Safe Talk suicide } \\
\text { awareness training. } \\
\text { - Reflections. } \\
\text { - Community resilience } \\
\text { mass casualty event. } \\
\text { - Palliative care planning } \\
\text { and ethical decision- } \\
\text { making. } \\
\text { - Immediate life support } \\
\text { training. } \\
\text { - Apply learning to achieve } \\
\text { effective teamwork and } \\
\text { leadership in preparation } \\
\text { for practice. }\end{array}$ & $\begin{array}{l}\text { Focused preparatory learning } \\
\text { Lecture } \\
\text { Tutorials } \\
\text { Concept based learning } \\
\text { activities } \\
\text { - Challenging video's } \\
\text { Case based learning } \\
\text { - In-depth case studies } \\
\text { - } \quad \text { Reflective practice } \\
\text { - Peer learning } \\
\text { High fidelity simulation } \\
\text { events with mannequins, } \\
\text { actors, emergency services, } \\
\text { local councils, community } \\
\text { members and voluntary } \\
\text { organisations }\end{array}$ & \\
\hline
\end{tabular}

Table 2: End-of-life within the curriculum design outlined by year 


\begin{tabular}{|c|c|c|c|}
\hline \multicolumn{4}{|c|}{ Was teaching delivered at the level that was appropriate to your needs? } \\
\hline Year & Yes & No & Question not answered \\
\hline \multirow[t]{2}{*}{ One } & \multirow[t]{2}{*}{$298(88.7 \%)$} & \multirow[t]{2}{*}{$30(8.9 \%)$} & $\mathrm{TF}=7(2.1 \%)$ \\
\hline & & & No answer $1(0.3 \%)$ \\
\hline Two & $326(97 \%)$ & $10(3 \%)$ & 0 \\
\hline Three & $298(88.7 \%)$ & $30(8.9 \%)$ & $8(2.4 \%)$ \\
\hline \multicolumn{4}{|c|}{ Was teaching delivered at the level that was appropriate to your needs? } \\
\hline Year & Yes & No & Question not answered \\
\hline \multirow[t]{2}{*}{ One } & \multirow[t]{2}{*}{$298(88.7 \%)$} & \multirow[t]{2}{*}{$30(8.9 \%)$} & $\mathrm{TF}=7(2.1 \%)$ \\
\hline & & & No answer $1(0.3 \%)$ \\
\hline Two & 326 (97\%) & $10(3 \%)$ & 0 \\
\hline Three & $298(88.7 \%)$ & $30(8.9 \%)$ & $8(2.4 \%)$ \\
\hline
\end{tabular}

Table 3. Appropriateness of teaching and learning to professional and personal learning needs

\begin{tabular}{|c|c|c|c|c|c|c|}
\hline \multicolumn{4}{|c|}{ Was teaching useful in your personal life? } & \multicolumn{3}{|c|}{$\begin{array}{l}\text { Was teaching useful in your clinical } \\
\text { practice experience? }\end{array}$} \\
\hline Year & Yes & No & Total answered & Yes & No & $\begin{array}{c}\text { Total } \\
\text { answered }\end{array}$ \\
\hline One & $\begin{array}{c}209 \\
(74.6) \%\end{array}$ & $\begin{array}{c}64 \\
(22.9 \%)\end{array}$ & $\begin{array}{c}\mathrm{TF}=7(2.5 \%) \\
280\end{array}$ & $\begin{array}{c}296 \\
(88.1 \%)\end{array}$ & $\begin{array}{c}32 \\
(9.5 \%)\end{array}$ & $\begin{array}{c}\mathrm{TF}=7(2.1 \%) \\
335\end{array}$ \\
\hline Two & $\begin{array}{c}230 \\
(82.1 \%)\end{array}$ & $\begin{array}{c}46 \\
(16.4 \%)\end{array}$ & 276 & $\begin{array}{l}326 \\
(97 \%)\end{array}$ & $\begin{array}{c}8 \\
(2.4 \%)\end{array}$ & 334 \\
\hline Three & $\begin{array}{c}222 \\
(81.7 \%)\end{array}$ & $\begin{array}{c}49 \\
(18.3 \%)\end{array}$ & 271 & $\begin{array}{c}301 \\
(89.6 \%)\end{array}$ & $\begin{array}{c}28 \\
(8.3 \%)\end{array}$ & 329 \\
\hline
\end{tabular}

Table 4. Usefulness of learning in personal life and clinical practice settings. 


\begin{tabular}{|c|c|c|c|c|c|}
\hline \multicolumn{2}{|c|}{ Year one } & \multicolumn{2}{|c|}{ Year two } & \multicolumn{2}{|c|}{ Year three } \\
\hline Response & Frequency & Response & Frequency & Response & Frequency \\
\hline $\begin{array}{l}\text { Introduction \& } \\
\text { insight into the } \\
\text { topic }\end{array}$ & $\begin{array}{c}155 \\
(46.1 \%)\end{array}$ & $\begin{array}{l}\text { Person- } \\
\text { centred } \\
\text { skills for } \\
\text { end-of-life } \\
\text { care }\end{array}$ & $\begin{array}{l}148 \\
(44 \%)\end{array}$ & $\begin{array}{l}\text { Increased } \\
\text { knowledge \& } \\
\text { confidence }\end{array}$ & $\begin{array}{c}106 \\
(31.5 \%)\end{array}$ \\
\hline $\begin{array}{l}\text { Prepared for } \\
\text { dealing with } \\
\text { death }\end{array}$ & $\begin{array}{c}117 \\
(34.8 \%)\end{array}$ & $\begin{array}{l}\text { Knowledge } \\
\& \text { practice of } \\
\text { breaking } \\
\text { bad news }\end{array}$ & $\begin{array}{c}115 \\
(34.2 \%)\end{array}$ & $\begin{array}{l}\text { Clearer insight } \\
\text { into palliative } \\
\text { care }\end{array}$ & $\begin{array}{c}49 \\
(14.6 \%)\end{array}$ \\
\hline $\begin{array}{l}\text { Increased self- } \\
\text { care \& self- } \\
\text { awareness }\end{array}$ & $\begin{array}{c}28 \\
(8.3 \%)\end{array}$ & $\begin{array}{l}\text { Insight into } \\
\text { the topic/ } \\
\text { reduced } \\
\text { levels of } \\
\text { stress \& } \\
\text { perception } \\
\text { of taboo }\end{array}$ & $\begin{array}{c}51 \\
(15.2 \%)\end{array}$ & $\begin{array}{l}\text { Developed } \\
\text { leadership \& } \\
\text { management } \\
\text { skills }\end{array}$ & $\begin{array}{c}40 \\
(11.9 \%)\end{array}$ \\
\hline $\begin{array}{l}\text { Framework for } \\
\text { having difficult } \\
\text { conversations }\end{array}$ & $\begin{array}{c}23 \\
(6.8 \%)\end{array}$ & $\begin{array}{l}\text { Increased } \\
\text { levels of } \\
\text { confidence }\end{array}$ & $\begin{array}{c}38 \\
(11.3 \%)\end{array}$ & $\begin{array}{l}\text { Community } \\
\text { resilience } \\
\text { event } \\
\text { experience }\end{array}$ & $\begin{array}{c}37 \\
(11 \%)\end{array}$ \\
\hline $\begin{array}{l}\text { Grieving } \\
\text { process \& } \\
\text { personal coping } \\
\text { mechanisms }\end{array}$ & $\begin{array}{c}22 \\
(6.5 \%)\end{array}$ & $\begin{array}{l}\text { Increased } \\
\text { knowledge } \\
\text { of family } \\
\text { needs }\end{array}$ & $\begin{array}{c}19 \\
(5.7 \%)\end{array}$ & $\begin{array}{l}\text { Ability to focus } \\
\text { on self-care }\end{array}$ & $\begin{array}{c}20 \\
(6 \%)\end{array}$ \\
\hline $\begin{array}{l}\text { Family support } \\
\& \text { care }\end{array}$ & $\begin{array}{c}18 \\
(5.4 \%)\end{array}$ & $\begin{array}{l}\text { Increased } \\
\text { self- } \\
\text { awareness }\end{array}$ & $\begin{array}{c}15 \\
(4.5 \%)\end{array}$ & $\begin{array}{l}\text { Increased self- } \\
\text { awareness }\end{array}$ & $\begin{array}{c}18 \\
(5 . \%)\end{array}$ \\
\hline $\begin{array}{l}\text { Understanding } \\
\text { person-centred } \\
\text { wishes or } \\
\text { values }\end{array}$ & $\begin{array}{c}9 \\
(2.7 \%)\end{array}$ & $\begin{array}{l}\text { Awareness } \\
\text { of other } \\
\text { faiths and }\end{array}$ & $\begin{array}{c}12 \\
(3.6 \%)\end{array}$ & $\begin{array}{l}\text { Specialist } \\
\text { guest speakers } \\
\text { on the topic }\end{array}$ & $\begin{array}{c}15 \\
(4.5 \%)\end{array}$ \\
\hline $\begin{array}{l}\text { Specialist guest } \\
\text { speakers on the } \\
\text { topic }\end{array}$ & $\begin{array}{l}5 \\
(1.5 \%)\end{array}$ & cultures & & $\begin{array}{l}\text { 'Final Journeys' } \\
\text { preparation }\end{array}$ & $\begin{array}{c}9 \\
(2.7 \%)\end{array}$ \\
\hline
\end{tabular}

Table 5. Specific aspects of learning about end-of-life care which the students found valuable 